\title{
AS REPRESENTAÇÕES SOCIAIS DO CONCEITO DE “APRENDER” NA EDUCAÇÃO INFANTIL
}

\section{ARTIGO ORIGINAL}

LIMA, Iris Ferreira De ${ }^{1}$

LIMA, Iris Ferreira De. As representações sociais do conceito de "aprender" na Educação Infantil. Revista Científica Multidisciplinar Núcleo do Conhecimento. Ano 05, Ed. 11, Vol. 14, pp. 127-166. Novembro de 2020. ISSN: 2448-0959, Link de acesso:https://www.nucleodoconhecimento.com.br/educacao/as-representacoes$\underline{\text { sociais }}$

\section{RESUMO}

Este trabalhado tem objetivo identificar as representações sociais sobre o conceito de aprender na Educação Infantil, para pais/responsáveis e docentes, com a relevância de verificar a obviedade deste conceito e destacar a importância da formação do discente nesta fase de escolarização. $O$ estudo foi realizado em duas unidades escolares, uma na zona rural e outra na zona urbana, ambas localizadas no Vale do Paraíba, interior de São Paulo. A fundamentação teórica está pautada na Teoria das Representações Sociais, no referencial da Base Nacional Curricular Comum sobre o conceito de aprender e nas teorias de Piaget, Vygotsky e Wallon. Esta é uma pesquisa de natureza qualitativa e quantitativa, com caráter exploratório. Os sujeitos participantes são 12 docentes ativos e 08 pais/responsáveis de alunos matriculados nas unidades escolares selecionadas para o estudo. Para a coleta de dados os instrumentos utilizados foram questionário e grupo focal. $\mathrm{O}$ tratamento dos dados se deu por meio da análise de conteúdo e compilação por meio de categorias tomando como referência os estudos teóricos de Bardin (2009) e a utilização do programa IRAMUTEQ. Diante dos resultados, pode-se verificar que as representações sociais sobre o conceito de "aprender" entre pais/responsáveis e docentes apresenta

\footnotetext{
${ }^{1}$ As representações sociais do conceito de "aprender" na Educação Infantil
} 
diferenças significativas quanto as expectativas dos conteúdos trabalhados na Educação Infantil, já que o conceito de aprender para os docentes está apropriado e familiarizado como prática docente em formar cidadãos de maneira global, enquanto que para os pais/responsáveis o conceito de aprender está diretamente associado à ação de alfabetizar. Tais diferenças são evidenciadas tanto na escola rural quanto na urbana. Constata-se que o conceito de aprender se baseia nas realidades práticas dos grupos participantes, que, de acordo com seus valores e crenças, o conceituam. Para ambos os grupos, a importância da Educação Infantil, passa a ter menos representatividade assistencial e mais educacional.

Palavras-Chave: Representações sociais, Educação Infantil, conceito de aprender.

\section{INTRODUÇÃO}

Com as novas perspectivas da educação para a elaboração de uma Base Nacional Curricular Comum (BNCC), isto irá refletir também em alterações na educação infantil, sendo então relevante compreender o conceito de aprender para os primeiros anos de escolarização.

Ao compreender este conceito é possível verificar o nível de influência destas representações na aprendizagem dos discentes, já que estes refletem o saber dentro e fora do ambiente escolar, considerando sua capacidade de adaptação e solução de problemas na vida cotidiana, sendo agentes influenciados e/ou influenciadores na sociedade em que estão inseridos.

- Sendo uma base formadora da Educação Básica, o reconhecimento da criança como sujeito de direitos situa a Educação Infantil como uma necessidade social, ocupando, no cenário da política educacional brasileiro, um espaço de significativa relevância.

- Vive-se um tempo no qual é possível perceber que devido as "transformações societárias aliadas aos movimentos sociais e estudos acerca da infância, tem sido intensificado o reconhecimento da importância da educação das crianças 
para o pleno desenvolvimento das potencialidades do ser humano" (ANDRADE, 2009, p. 21).

- Assim sendo, há uma intensificação no processo de ampliação de um atendimento a criança pequena, com foco no caráter educacional, momento em que este ganha maior centralidade nas políticas educacionais. E com as propostas do Estado para ter um currículo comum a nível nacional, o estudo aqui proposto toma como referência, a definição elaborada pela Base Nacional Curricular Comum (BNCC, 2017), sobre o conceito de aprender na Educação Infantil, como objeto de estudo.

- Na BNCC (BASE NACIONAL CURRICULAR COMUM, 2017), o conceito de aprender para crianças pequenas, é definido como um processo de formação integral que deve desenvolver as competências necessárias para que os alunos possam atuar e transformar sua realidade, buscando construir uma sociedade verdadeiramente democrática, levando em consideração as diversidades e necessidades que constituem o cenário da educação (BRASIL, 2017).

- A partir do momento que o conceito de aprender estiver explícito para os docentes e pais/responsáveis, será possível aos professores nortearem suas ações pedagógicas para atingir tal objetivo, assim como para os pais/responsáveis será possível mensurar os resultados destas ações na sua realidade prática.

- Os docentes ao ter bem claro o conceito de aprender, em todas as suas atividades, como planejamentos, projetos, dentre outras ações na sua prática diária, também estarão voltados para este conceito e para o objetivo que o mesmo propõe alcançar.

- Assim sendo, quando um professor propõe uma atividade, é preciso estar claro que esta deverá ter o foco voltado para a formação integral do discente, buscando preparar o aluno para conhecer o mundo que o cerca, e que deve proporcionar mudanças na realidade do mesmo; pois só assim a atividade será realmente intencional, ou seja, a proposta de trabalho do docente estará de fato atendendo ao conceito de aprender. Mas, se isto não ocorre, perde-se o sentido da proposta, a atividade deixa de ter a objetividade para o aprender. 
- Para os pais/responsáveis ter o conceito de aprender evidente, estes conseguirão mensurar se seus filhos estão aprendendo, se estão ampliando seu conhecimento, assim como será possível a eles dialogar sobre as práticas pedagógicas com os docentes, sobre as expectativas de ensino-aprendizagem para os discentes, e outros assuntos pertinentes ao aprender, na Educação Infantil.

- É importante, para pais/responsáveis, saber que o aprender vai além de uma etapa da escolarização, pois há muito mais para acrescentar na vida do discente, e que este saber fará parte de toda a caminhada do aluno, pois o conhecimento será aplicado em todo o seu percurso de vida. Assim sendo, os pais precisam saber o que a criança aprende em todos os momentos na Educação Infantil, seja na sala de aula, no refeitório, no banheiro, na sala interativa, na rotina de entrada e saída da escola, na interação com o colega, com o professor, dentre outras situações.

- A cada passo que o aluno realiza no contexto escolar, ele estará se conhecendo, também conhecendo e se apropriando do mundo em que está inserido, e se esta etapa for bem elaborada, o aluno terá uma base educacional alicerçada em um saber capaz de promover um aprender que ele levará além dos limites da escola, e assim de fato será possível confirmar que o ensino e a aprendizagem foi eficiente.

- Neste sentido, é preciso ter claro o ponto de partida, a referência que justifique todas as ações pedagógica, este conceito vai além de uma (s) ou outra (s) prática (s) de ensino e aprendizagem, ele abrange toda a ação dentro do contexto escolar, e a eleva para algo mais amplo, que envolve vários aspectos da vida do sujeito e sua interação com o mundo.

- Portando, ao proporcionar docentes e pais/responsáveis a obviedade do conceito de aprender, isto ampliará também os horizontes dos mesmos sobre o ensino-aprendizagem, e a importância da Educação Infantil para a formação dos discentes.

- Assim sendo, a relevância deste estudo está em estudar as representações sociais dos docentes e pais/responsáveis sobre o conceito de aprender na Educação Infantil, por meio da Teoria das Representações Sociais. Esta teoria 
ressalta o estudo das relações sociais que nesta pesquisa, parte da análise do contexto social, a escola, em que os sujeitos estão inseridos.

- No contexto da escola, os indivíduos são influenciados pelas relações estabelecidas pelos membros da comunidade escolar, e a partir destas relações que são constituídos os pensamentos que serão ancorados e objetivados pelos sujeitos, de modo a permanecer como estão, ou serão modificados a partir das reflexões realizadas pelos indivíduos.

- Portanto, ao considerando o objeto referencial, o conceito de "aprender", é importante verificar se os participantes da pesquisa compartilham dos mesmos pensamentos, valores e crenças ou não. Assim como, ao refletir sobre este objeto, se os seus pensamentos serão mantidos ou modificados.

\section{DESENVOLVIMENTO}

\subsection{CONCEITOS BÁSICOS SOBRE A TEORIA DAS REPRESENTAÇÕES SOCIAIS}

A Teoria das Representações Sociais se propõe a estudar como se dá a construção do mundo interno do sujeito a partir das relações sociais vividas por ele. A partir das suas vivências no mundo objetivo o sujeito é influenciado para criar a sua subjetividade, sobretudo suas interações sociais são um fator constitutivo da sua subjetividade (BOCK; FURTADO e TEIXEIRA, 2007).

A Psicologia Social considera o homem como um ser social por natureza, e que vai além da objetividade do comportamento em sociedade, é a necessidade do homem em movimento, que cria e transforma sua relação com o mundo interno, a partir dos conteúdos externos, que influenciam constantemente seu processo de mudança, mesmo que aparentemente não fosse observável (BOCK; FURTADO e TEIXEIRA, 2007).

O homem enquanto ser social, constrói a si mesmo e ao mesmo tempo constrói a sociedade e a história. Então, para se compreender este homem social e sua 
movimentação e transformação do/no mundo, é necessário analisar sua atividade, consciência e identidade (BOCK; FURTADO e TEIXEIRA, 2007).

Entende-se por atividade a relação de construir e transformar o mundo, que simultaneamente será feito no mundo interno e externo do homem, pois a medida que o sujeito se apropria do meio em que está inserido, isto impacta em sua "psique", e desta forma o sujeito torna-se um eterno "vir a ser" de um novo sujeito (BOCK; FURTADO e TEIXEIRA, 2007).

A consciência é a capacidade do homem de fazer uma leitura do mundo objetivo, compreender este mundo, transformá-lo em ideias e imagens, e a partir destas informações entender o que se produz no mundo objetivo, apropriando-se de um "saber". Este saber é a apropriação dos conteúdos vivenciados no trabalho, na vida pessoal, nas relações sociais, que possibilitam o homem apropriar-se não só da sua experiência presente, mas também da construção de um mundo, por meio da cultura e história já feita por outros homens ao longo do tempo, e possibilitar verificar novas formas de construir o seu futuro (BOCK; FURTADO e TEIXEIRA, 2007).

Para expressar a consciência humana o indivíduo utiliza da linguagem. É por meio desta, que as ideias são compartilhadas e as representações do mundo objetivo são construídas coletivamente e com sentido para o sujeito, ou seja, a partir da vivência em sociedade (BOCK; FURTADO e TEIXEIRA, 2007).

A identidade é, portanto, a representação do sujeito sobre si mesmo, considerando-o como totalidade, mas que ao mesmo tempo busca a sua singularidade em confronto com o outro. E por ser um ser social, em constante transformação, a identidade "é um contínuo de representações de seu, estar sendo, no mundo." (BOCK; FURTADO e TEIXEIRA, 2007, p.145). Portanto, a Psicologia Social, veio a contribuir para compreender como o homem em sociedade faz, pensa e age diante do mundo.

Partindo deste ponto de vista, outros estudiosos, propõem entender estas representações sociais feitas pelo homem para compreender e verificar as transformações tanto no mundo objetivo quanto no subjetivo a qual faz parte. 
Durkheim foi o primeiro a identificar os objetos sociais, que podem ser imaginários ou reais, como por exemplo um evento, um material psíquico ou social, um fenômeno, uma ideia, uma teoria), como produções mentais sociais, em um estudo da "ideação coletiva". Ele ainda define os conceitos "representações individuais", sendo objeto de estudo da psicologia e as "representações coletivas", como objeto de estudo da sociologia.

Na década de 1960, com base na psicologia social e na proposta de Durkheim sobre as representações, Serge Moscovici, em seus estudos propõe o conceito de representações sociais, sendo assim, as representações se baseiam em "ideações sociais", o que marca um novo olhar para a psicologia social propondo o estudo das representações sociais a partir das relações do sujeito com a sociedade, e que podem ser compreendidas por meio do comportamento simbólico manifesto em seus hábitos, valores, crenças, etc., que estão presentes no nosso cotidiano.

Para Moscovici (2011), as representações sociais circulam, se intercruzam e se cristalizam continuamente, por meio de palavras, gestos, reuniões, que diante da comunicação compartilhada entre os sujeitos, se tornam quase que tangíveis no mundo cotidiano.

Sendo assim, o homem vivendo em sociedade participa ativamente dos processos sociais, sendo agente preservador ou transformador destes, e que ao mesmo tempo impactam na sua vivencia pessoal diante das experiências de estar no mundo (MOSCOVICl, 2011).

Portanto, "representar socialmente envolve a compreensão de valores e crenças que compõem uma sociedade. As representações surgem da necessidade de se compreender o desconhecido, de tornar estável o que causa instabilidade." (CHAMON, 2009, p.41).

O homem social vive em um mundo em que as coisas estão em constante mudanças, e ao se deparar com o novo acaba tendo que criar uma representação sobre o desconhecido, ou seja, a instabilidade de cada ato de conhecer o mundo, acaba por 
gerar um propósito de familiarização, tornando o que não se conhece algo conhecido, e este processo ocorre sobre tudo de forma coletiva, em que o conhecimento é construído e partilhado entre todos da sociedade (MOSCOVICI, 2011).

Um modo observável deste processo de conhecer e partilhar as representações sociais é feito pelo o homem social por meio da linguagem, que é a forma simbólica para organizar seu pensamento, mas a maneira de pensar e o que pensa depende das representações, ou seja, depende do fato do sujeito ter ou não a representação de tal "objeto" (MOSCOVICI, 2011).

Segundo Moscovici, (2011, p. 51) "[...] se nós pensamos antes de falar e falamos para nos ajudarmos a pensar, nós também falamos para fornecer uma realidade sonora à pressão interior dessas conversações, por meio das quais nós nos ligamos aos outros."

A comunicação na sociedade tem o papel fundamental de favorecer ao sujeito a capacidade de representar o mundo seu pensamento, de modo que os outros também possam compreender, se apropriar das representações e partilhar, constituindo assim a cultura, a história e a própria natureza humana (JODELET, 2001).

Como define Jodelet (2001, p.22) a representação social "[...]é uma forma de conhecimento, socialmente elaborada e partilhada, com um objetivo prático, e que contribui para a construção de uma realidade comum a um conjunto social."

Portanto, cabe neste contexto ressaltar que a escola é um ambiente social, repleto de representações, que são partilhadas por todos os membros envolvidos no processo de ensino aprendizagem, de forma prática contida no cotidiano dos sujeitos que conhecem por meio do coletivo a forma de pensar a sociedade em que estão inseridos.

A escola é então um ambiente de socialização e que representa para a sociedade uma formalização reconhecida pela coletividade de transmissão do conhecimento socialmente acumulado. 
Para Chamon (2009, p.3), [...] "ainda que exista a apropriação/reconstrução individual das representações sociais, elas transbordam a vida mental do indivíduo isolado e formam uma realidade própria, compondo a identidade de um grupo social, orientando e justificando suas práticas sociais."

Como afirma Moscovici (2011, p.40) o processo coletivo penetra como um fator determinante dentro do pensamento individual, estas representações sociais aparecem, quase como que objetos materiais, pois são o produto das ações e comunicação do sujeito.

É, também na escola que o indivíduo tem o acesso as representações, sendo capaz de no processo de interação representá-las, preservá-las ou modificá-las.

Para Jodelet (2001), as representações sociais possibilitam ao sujeito compreender o mundo em que está inserido e dominá-lo, por meio de reinterpretação e elaboração de conceitos, sem assim os indivíduos passam a se apropriar de saberes.

Esta apropriação, é a forma de tornar o sujeito consciente do mundo em que está inserido e ao mesmo tempo ciente de si mesmo, enquanto ser no mundo e agente transformador deste.

Moscovici (2011) ressalta que uma representação é uma forma de conhecimento prático, conectando um sujeito a um objeto, e neste sentido para se quantificar esse conhecimento é preciso considerar a experiência, os referenciais e condições a partir da qual ele é produzido, e sobretudo como esta representação é empregada no contexto social.

Então, para se compreender o contexto escolar, é preciso compreender as diversas representações sociais que nele estão contidas.

\section{A BNNC E OS PRESSUPOSTOS PARA A EDUCAÇÃO INFANTIL}


A educação brasileira na intenção de promover a formação humana integral e a construção de uma sociedade mais justa, democrática e inclusiva tem tido grandes desafios a serem enfrentados.

Com a Base Nacional Comum Curricular, o Estado vem cumprir esse papel de propor mudanças, visto que é necessário promover e garantir a todos os alunos oportunidades, permanência, aprendizado e desenvolvimento como direito, e assim a equidade e igualdade estarão presentes de fato no processo educacional, fornecendo um ensino de qualidade e significativo para a população brasileira (BNCC, 2017).

Neste sentido, a Base Nacional Curricular Comum (2017) e os currículos se identificam na comunhão de princípios e valores que reconhecem que a educação tem um compromisso com a formação e o desenvolvimento humano global, em suas dimensões intelectual, física, afetiva, social, ética, moral e simbólica.

Contudo, é importante considerar que no Brasil, com autonomia dos entes federados, a acentuada diversidade cultural e profundas desigualdades sociais, buscar por equidade na educação, ressalta a necessidade de currículos diferenciados e adequados a cada sistema, rede e instituição escolar. (BNCC, 2017).

Neste sentido, é preciso verificar se realmente cabe a proposição de um currículo nacional, diante de um cenário educacional tão diversificado e com desigualdades sociais bastante significativas.

Sendo assim, a BNCC (2017), vem propor que na área da educação possa se trabalhar com as competências necessárias para que os alunos tenham uma formação integral, e assim ser agentes transformadores da sua realidade, construindo uma sociedade com equidade e igualdade, mas considerando as diversidades e necessidades de todos os sujeitos envolvidos no processo escolar.

Considerando o termo competência, as concepções elaboradas na BNCC (2017), para explicar o foco desta proposta e definição do termo, destaca que para a Educação Infantil, o foco do currículo escolar, será de valorizar e utilizar os conhecimentos historicamente construídos sobre o mundo físico, social e cultural para 
entender e explicar a sua realidade colaborando para a construção de uma sociedade melhor. Para alcançar este objetivo as práticas pedagógicas nas escolas deverão desenvolver nos alunos competências significativas.

Estas competências englobam de acordo com a BNCC (2017), exercitar a curiosidade intelectual dos estudantes, recorrendo à abordagem própria das ciências, que é, investigar, elaborar e testar para então formular e resolver problemas, com base nos conhecimentos de diferentes áreas.

Deverá desenvolver o senso estético, por meio de diversas manifestações artísticas e culturais, sejam elas locais ou mundiais.

Propor diferentes formas de utilizar das linguagens: verbal e/ou verbo-visual (como Libras), para proporcionar diferentes contextos para gerar oportunidades de expressar ideias e sentimentos que leve produzir sentidos e entendimentos mútuos

Propor ações para que os alunos tenham acesso e utilizem as tecnologias digitais em seu cotidiano, assessorando a comunicação, e também produzir conhecimentos e facilitar a resolução de problemas.

Levar os sujeitos a se apropriarem dos saberes e vivências do mundo em que está inserido possibilitando compreender as relações do mundo do trabalho e a capacidade de fazer suas escolhas de forma assertiva.

Desenvolver um posicionamento ético nos alunos, considerando os direitos humanos e a consciência socioambiental, respeitando a si mesmo, o outro e o planeta.

Possibilitar aos estudantes, ações que promovam o auto - conhecimento, aprendendo a lidar com as suas emoções e com a dos demais, estabelecendo relações interpessoais adequadas, com acolhimento e valorização da diversidade de indivíduos e de grupos sociais, sem preconceitos de origem, etnia, gênero, idade, habilidade/necessidade, convicção religiosa ou de qualquer outra natureza, reconhecendo-se como parte de uma coletividade com a qual deve se comprometer. 
Deste modo o aluno será conduzido pela escola a construir seja a nível individual ou coletivo, princípios éticos inclusivos, sustentáveis e solidários, para de fato ele se tornar cidadão participativo e transformador de uma sociedade.

Considerando a proposta de educação e as competências apresentadas na BNCC, esta vem apresentar uma estrutura em que se pode entender cada etapa de escolaridade para a educação, considerando neste trabalho as etapas da Educação Infantil.

Para a BNCC (2017), a estrutura da Educação Infantil compreende assegurar o direito de aprendizagem e desenvolvimento dos alunos, por meio de seis (06) eixos que são definidos como: Conviver, Brincar, Participar, Explorar, Expressar, Conhecer-se. Estes eixos serão trabalhados considerando cinco (05) campos de experiências, que são: O eu, o outros e o nós; Corpo, gestos e movimentos; Traços, sons, cores e formas; Oralidade e escrita; Espaços, tempos, quantidades, relações e transformações. Estes campos de experiências serão comtemplados e organizados de acordo com três (03) grupos de faixas etária que são: 0 a 1ano e seis meses; 1 ano e sete meses a 3 anos e 11 meses; 4 anos a 5 anos e 11 meses.

Os seis (06) eixos estruturantes para a prática pedagógica propostas na BNCC (2017), vem assegurar os direitos de aprendizagem e desenvolvimento, por meio de interações e brincadeiras que são pertinentes a educação básica para os infantis de 0 a 5 anos, com uma intencionalidade educativa presente em todas as práticas pedagógicas na Educação Infantil.

Para que este objetivo seja alcançado na Educação Infantil a BNCC (2017), propõe que as práticas educativas nas unidades escolares devam promover o convívio das crianças com outras crianças e adultos, favorecendo as interações entre os sujeitos e estimulando o respeito entre as culturas e diferenças entre as pessoas.

Ressalta que o brincar deva ocorrer de diversas formas e em diferentes espaços e tempos, contribuindo para ampliar e diversificar os conhecimentos dos alunos por meio da valorização das brincadeiras e pelo desenvolvimento de ações que 
despertem a imaginação, criatividade, experiências emocionais, corporais, sensoriais, expressivas, cognitivas, sociais e relacionais.

$\mathrm{Na}$ Educação Infantil também deve ser um espaço democrático e atuante do aluno diante da gestão escolar e das atividades propostas como por exemplo, promovendo momentos em que os alunos possam escolher brincadeiras, materiais e ambientes, promovendo. Assim o aluno poderá desenvolver habilidades para decidir e se posicionar, diante das situações propostas.

A escola também deve ser o espaço para ampliar os saberes sobre a cultura em que o aluno está inserido e outras culturas diferentes da sua, utilizando diversos tipos de materiais e recursos que possam promover o conhecimento e a aprendizagem, explorando diferentes recursos dentro e fora da escola.

Por meio de práticas estruturadas o aluno deverá explorar movimentos, gestos, sons, formas, texturas, cores, palavras, emoções, transformações, relacionamentos, histórias, objetos, elementos da natureza, por meio de produções em artes, escrita, ciência e em tecnologia.

Oportunizar ao sujeito na unidade escolar momentos de se expressar de forma criativa e sensível, estabelecendo um diálogo adequado por meio de diferentes linguagens, tornando possível ele realizar hipóteses e descobertas, emitir opiniões e fazer questionamentos, para atender suas necessidades, emoções e sentimentos assim como esclarecer suas dúvidas sobre o mundo o que cerca.

Estas ações devem também possibilitar ao estudante construir a sua identidade (pessoal, social e cultural), alicerçando a imagem positiva de si mesmo, por meio de diversas experiências que a escola, a família e a comunidade podem promover aos alunos, seja pelos cuidados, pelas interações, brincadeiras ou diferentes linguagens.

Já os cinco (05) campos de experiências estão descritos na BNCC (2017), considera que a escolas devam trabalhar com base no campo 1, as interações sociais para formar percepções sobre si mesmo e sobre os outros, deve participar de relações 
sociais e de cuidados pessoas para construir sua autonomia e senso de autocuidado, de reciprocidade e interdependência com o meio.

Portanto, é preciso criar oportunidades para que os estudantes tenham possibilidades de ampliar a maneira de perceber a si mesmos e aos outros, de valorizar sua identidade, de respeitar as diferenças, que nos constituem e nos torna seres humanos e únicos em sua essência.

No campo 2, a proposta é trabalhar o corpo, por meio de diferentes linguagens, oferecendo a criança conhecer e reconhecer suas emoções, funções corporais e nos seus gestos e movimento, a identificar suas potencialidades e seus limites. Diante desta consciência corporal o aluno poderá compreender o que é seguro e o que é risco, aprendendo também a cuidar de si mesmo, e manter a sua integridade física.

Na Educação Infantil, por meio das práticas lúdicas e na interação social as crianças são levadas a cuidar do físico, orientadas para a independência e a liberdade, podendo explorar e vivenciar um repertório diversificado de movimentos com o corpo descobrindo formas diferentes de estar no mundo, sem se sentir subjugado.

No campo 3, a orientação é de vivenciar diferentes formas de expressão e linguagem, tendo acesso a diferentes manifestações artísticas, culturais e científicas. Também deve proporcionar aos alunos que eles também exercitem a autoria e criem suas próprias produções.

Estas práticas escolares favorecem desde cedo que a criança desenvolva sua sensibilidade, senso crítico, a capacidade de apreciar, manifestar e produzir, diante de suas experiências e vivencias artísticas.

No campo 4, ressalta a importância de linguagem oral, com ações que possam favorecer falar e ouvir, ampliando o vocabulário e assim como desenvolvendo a internalização das estruturas linguísticas mais complexas e a concepção da língua escrita. 
As muitas possibilidades de aproximar a criança da leitura e da escrita, faz com que a mesma desenvolva as suas hipóteses para a aprendizagem para ser e escrever, assim como a compreensão da escrita como representação da oralidade.

E no campo 5, o foco está em inserir a criança no mundo por meio de diversos espaços e tempos, quantidades, relações e transformações, favorecendo a observação dos fenômenos, a manipulação de objetos, a investigação e exploração de tudo ao seu redor. Por meio destas ações o aluno irá levantar hipóteses e irá buscar respostas para elas, assim irá conhecer melhor o mundo em que está inserido.

A BNCC (2017), apresenta também uma síntese das aprendizagens, descrevendo para cada campo de experiências o que é essencial para o aluno aprender, para que a transição da Educação Infantil para o ensino fundamental seja eficiente. Esta síntese, norteará os envolvidos no processo educacional do país, no que se refere ao que será esperado para uma transição de qualidade, com o objetivo de interagir e dar continuidade nas aprendizagens dos discentes, tornando estes elementos apresentados na síntese, indicadores referenciais para todo o trabalho realizado na primeira etapa da Educação Infantil Brasileira (2017).

Tanto os eixos quanto os campos experienciais segundo a BNCC (2017), precisam ser trabalhados de forma a considerar as três (03) faixas etárias sendo que as duas primeiras são caraterizadas por alunos das creches que compreende a faixa etária de 0 a 01 ano e 6 meses e a outra faixa de 1 ano e 7 meses a 3 anos e 11 meses, e posteriormente a faixa de 04 a 5 anos e 11 meses que compreende os alunos da préescola. Mas, estas faixas etárias não podem ser consideradas de forma rígida, pois sobretudo os grupos de faixas etárias podem apresentar crianças com características diferentes, com ritmo de aprendizagem e desenvolvimento que necessitarão de uma prática pedagógica que respeite estas diferenças, facilitando o aprender e a superação da etapa da Educação Infantil de modo que a transição para o ensino fundamental de forma adequada e eficaz.

$\mathrm{Na}$ Educação Infantil também há o processo de avaliação, considerando que a criança está em determinada fase de desenvolvimento e que em seu contexto há o cuidar, o 
brincar e o educar. A avaliação deve contemplar a prática diária de ensinar e aprender, construindo assim um contínuo processo de desenvolvimento educacional.

Partindo deste ponto de vista, a avaliação na Educação Infantil, deve ser formativa, ou seja, aquela que "[...] contribui para a regulação das aprendizagens em curso no sentido dos domínios visados." (PERRENOUD, 1999, p.77).

$\mathrm{Na}$ Educação Infantil o processo de avaliar é contínuo e diário, com a possibilidade de visualizar o resultado que se deseja alcançar, mas não é só este fim, mas sobretudo por meio de atividades diversificadas e registros significativos, que o professor irá contribuir para a aprendizagem do aluno, verificando seus avanços, suas permanências e retrocessos diante dos conteúdos aprendidos. Assim, o aprender é não só do discente como também do docente, que precisa refletir, avaliar e aprender novas formas de ensinar para atuar de forma consciente do seu papel (PERRENOUD, 1999).

Tomando esta perspectiva de avaliar na Educação Infantil, o objetivo de reter ou promover o aluno perde o significado, e passa a ter o sentido de acompanhar a evolução do discente, e verificar o quanto ele progrediu diante do que the foi oferecido no contexto em que está inserido. Isto se confirma na Lei de Diretrizes e Bases da Educação Nacional, Lei 9.394: Art. 31, "na Educação Infantil a avaliação far-se-à mediante acompanhamento e registro de seu desenvolvimento, sem o objetivo de promoção, mesmo para o acesso ao ensino fundamental." (BRASIL, 1996).

Avaliar é um processo complexo que envolve um olhar crítico do professor sobre a sua prática pedagógica, inserida no contexto escolar repleto de exigências e diversidades, que impactam nas expectativas de pais, alunos, diretores, coordenadores, comunidade, Estado e do próprio professor, mas é inerente a escola saber o quanto o aluno progrediu e em virtude disto há de se estabelecer um recurso para isto, e se este for bem entendido e aplicado terá atingido seu objetivo (RAIZER, 2009). 


\section{CONTRIBUIÇÕES TEÓRICAS: REFERÊNCIAS PARA COMPREENDER O PROCESSO DE DESENVOLVIMENTO E APRENDIZAGEM DA CRIANÇA}

Ao longo da história da educação muitas contribuições vieram de diferentes áreas de estudo, para um melhor entendimento da criança e seu processo de desenvolvimento e aprendizagem, mais especificamente a partir do século XVIII, a criança passa a ser vista pela sociedade como sujeito com necessidades e objeto de expectativas e cuidados. Neste sentido, muitas ideias surgiram como caminhos para educar os infantis.

Como as contribuições teóricas, de Piaget, Vygotsky e Wallon, para compreender o processo de desenvolvimento e aprendizagem da criança.

Para Piaget, e sua teoria baseada no interacionismo, conceito este que ressalta que o indivíduo aprende a partir das relações que ele estabelece com o meio em que está inserido, considerando toda sua cultura e história. O sujeito é um ser que age com o meio, e é neste processo que ele é capaz de adquirir o conhecimento sobre o mundo. Mas, para que a aquisição seja efetiva, é necessário verificar qual o nível das estruturas cognitivas do mesmo, ou seja, o sujeito só é capaz de aprender se ele cognitivamente conseguir refletir sobre o seu saber. Para ele era importante saber como o sujeito então adquiri o conhecimento e assim se constituem como seres humanos, diferente dos outros seres (TRISTÃO, 2010).

Para isto, ele propôs uma abordagem prática para analisar o comportamento infantil, e verificar como se constituía o pensamento, considerando os estágios de desenvolvimento.

Piaget, também ressalta que a aquisição de conhecimento é gradativa, mas para que a progressão seja positiva, o sujeito necessitaria de estabelecer um processo de equilibração. A equilibração seria consolidada à medida que as estruturas cognitivas fossem capazes de processar o novo saber (CARVALHO, 2005). 
Em um primeiro momento, o sujeito sofreria um desequilíbrio, que seria por exemplo as dúvidas, problemas, vontades e necessidades a serem atendidas, que impulsionaria o indivíduo a buscar resolver estes dilemas. Para isto, ele direcionaria seus esforços para este fim e assim aprenderia coisas novas, efetivamente a aquisição de um novo saber (TRISTÃO, 2010).

O processo de equilibração seria um sistema de compensação, entre as possíveis solicitações do meio ambiente e as necessidades do sujeito de supri-las. Portanto, a aprendizagem para Piaget, seria a consolidação do conhecimento de forma duradoura a partir da equilibração, por meio das experiências adquiridas na interação com o meio ambiente.

A cada busca por equilibração, ocorreria de forma diferencia de acordo com as faixas etárias, assim os esquemas mentais e ações aplicadas pelos sujeitos, dependeria do nível de desenvolvimento cognitivo do mesmo, o que fundamenta seu conceito de esquema de ação ou de esquema mental (TRISTÃO, 2010).

Piaget aponta que os esquemas de ação, são aqueles que o sujeito utiliza para se adaptar e organizar o meio em que vive, à medida que estes esquemas vão sendo coordenados, diferenciados e posteriormente interiorizados e com o auxílio da linguagem, eles passam a formas esquemas mentais, ou melhor dizendo formando $o$ pensamento do indivíduo (TRISTÃO, 2010).

Com a aquisição dos esquemas mentais o sujeito não necessária mente precisa agir diretamente com o meio, mas se torna capaz de antecipar ações antes de realiza-las, por meio do pensamento, como uma ação interiorizada. Estas interiorizações vão se tornando cada vez mais complexas e abstratas. O sujeito passa então a pensar e compreender abstrações, o que é fundamental para a aprendizagem de tempo, massa, espaço, velocidade, distância dentro outros conceitos fundamentais para a aprendizagem.

A aprendizagem nos postulados de Piaget, seria um ciclo, que envolve o estado de equilíbrio cognitivo do sujeito, mas diante do meio em que está inserido e a 
necessidade de interação com o mesmo, o sujeito sofreria o desequilíbrio, sendo assim precisaria recorrer aos esquemas mentais e de ação para se adaptar ao meio, assimilando e acomodando os novos saberes, e assim voltando novamente ao estado de equilibração.

Carvalho (2005), diz que tal posicionamento ratifica a ênfase que atribui à equilibração como fator principal do desenvolvimento, pois uma descoberta envolve sempre assimilação e acomodação das estruturas cognitivas, um jogo de regulações e compensações.

Este processo de equilibração, envolvendo a assimilação e acomodação, acontece durante todo a nossa vida, mas que ocorrem de forma diferente de acordo com os vários estágios de desenvolvimento cognitivo do sujeito, sendo assim, em cada estágio há a aplicabilidade de esquemas ação e esquemas mentais diferentes.

Carvalho (2005) ressalta que se o desenvolvimento envolve estágios ordenados e sucessivos e depende, fundamentalmente, do processo de equilibração, a aprendizagem escolar fica subordinada às estruturas de pensamento já construídas pela criança.

Piaget, aborda quatro tipos de estágios de desenvolvimento, que seria o primeiro estágio o sensório-motor, o segundo estágio o pré-operatório, o terceiro estágio o operatório concreto e por fim o estágio operatório formal (TRISTÃO, 2010).

No primeiro estágio, sensório motor que compreende a faixa etária de zero aos dois anos de idade. Nesta fase a criança apresentara um desenvolvimento que compreende os comportamentos reflexos, a organização das percepções e hábitos e posteriormente a inteligência sensório motora (PIAGET, 1989).

Como descreve Tristão (2010) para o recém-nascido os primeiros comportamentos são os reflexos sensórios motores, como por exemplo a sucção, quando o bebê alimenta. Com o tempo, o bebê emite este comportamento diante de outros objetos, então passa de forma impulsiva a interagir com o mundo e seus reflexos tornam-se mais complexos, e assim o recém-nascido passa a ter hábitos e percepções sobre o 
meio em que está inserido. Na fase seguinte a criança passa a reconhecer os estímulos do ambiente e a responder a eles de forma mais organizada, mas ainda a criança está centrada em si mesmo, não diferencia objetos de pessoas, e os seus comportamentos estão mais direcionados aos seus impulsos para satisfazer suas necessidades. Quando chega a fase da inteligência sensório motora, a criança já passou pelas etapas anteriores, seu comportamento foi progressivamente sendo modificado e se tornando cada vez mais complexo, chegando aos esquemas de ação. A cada ação a criança vai conhecendo melhor o mundo que a cerca, e passa então da diferenciar os objetos, a reconhecer pessoas e a perceber um mundo fora de si mesmo.

Considerando a aprendizagem, esta fase de desenvolvimento é importante, pois a criança já é capaz de construir a categoria de objeto, do espaço, da causalidade e do tempo. A criança agora é capaz de perceber o objeto e/ou pessoa; desenvolve movimentos coordenados no espaço e reconhece seu próprio corpo, percebe as relações de causa e efeito, percebe a ordem de acontecimentos que sucedem na sua rotina, e de forma consegue analisar o mundo a sua volta, deixa a fase egocêntrica e passa ter sentimentos em relação aos objetos e a pessoas, como por exemplo, alegria ou tristeza, sucesso ou fracasso.

O segundo estágio que corresponde ao pré-operatório corresponde a faixa estaria de dois a sete anos de idade, e que é caraterizado pelo aparecimento da linguagem, tornando a criança capaz de narrar suas ações passadas e antecipar suas ações futuras, expressando de forma verbal seu comportamento.

Para Piaget, a linguagem possibilita a criança o início da socialização das ações, a imitar e emitir sons estabelecendo uma comunicação com o outro, e também surge a fala egocêntrica, que são os monólogos que a criança estabelece com ela mesma. Estes novos comportamentos, na fase pré-operatória, favorecem a constituir o pensamento. Nesta fase também se destaca os jogos simbólicos e a capacidade da criança de reviver sua própria vida por meio do brincar, e ao fazer estes jogos surgem também os questionamentos sobre o mundo, os "porquês" aparecem como forma de buscar explicações os fatos, mas como ainda possui uma fala egocêntrica, as 
respostas para seus questionamento são ainda por meio da intuição, já que a criança ainda não tem a capacidade da mobilidade e reversibilidade que será apresentada na próxima fase (PIAGET, 1989)

A criança também desenvolve suas primeiras noções de valor e moral, partindo da interação com os outros, por exemplo, a criança não tem consciência de que a mentira é algo ruim, mas passa a pensar sobre quando um adulto lhe diz que isto não é bom (TRISTÃO, 2010).

No estágio operatório-concreto que começa por volta dos sete anos e se estende até os doze anos, fase que corresponde também o período de escolarização, e que há muitas mudanças no comportamento do sujeito em relação a sociabilização, ao seu pensamento, as suas operações racionais e a sua afetividade.

A criança nesta fase passa a ter mais autonomia dos seus pensamentos, começa a perceber as regras e a respeitá-las, refletindo sobre suas ações e assim deixando suas condutas impulsivas de lado e passa agora a "decidir" como irá se comportar diante das situações, Neste sentido a criança busca entende melhor as relações de causa e efeito nas suas ações e dar explicações sobre as suas atitudes. Os jogos de regras e coletivos, tornam-se interessantes, a criança procura dispensar sua atenção para brincar e compartilhar com os demais (PIAGET, 1989).

Nesta fase a aprendizagem tem um grande salto pois que a criança agora já é capaz de ter noções de conservação de substâncias, volume, peso, comprimento, superfícies, além de tempo e espaço como os adultos. O pensamento de reversibilidade também é característico nesta etapa de desenvolvimento e aprendizagem, assim como a noção de número e o domínio das operações aritméticas.

Como afirma Piaget (1989), a passagem da intuição para a lógica, ocorre na segunda infância, pela construção de agrupamentos e grupos, constituindo organizações de conjuntos, que são solidários e equilibrados entre si. 
Esta fase também é marcada pela capacidade da criança de ter respeito mútuo, ter sentimentos de justiça, compreende conceitos como honestidade e companheirismo, ampliando de forma significativa seu repertório de aprendizagem e aplicabilidade na sua realidade prática.

Após este salto significativo no pensamento, linguagem e comportamentos, inicia-se o último estágio, para Piaget, que começa aos doze anos e se estende até a fase adulta.

No estágio formal a criança, entra na fase da adolescência, marcada por muitas mudanças emocionais, mas também do pensamento abstrato, baseado em hipóteses, que Piaget chama de hipotético-dedutivo, ou seja, agora ele é capaz de refletir sobre os fatos, levantar hipóteses e deduzir as conclusões baseado somente nestas. O adolescente acredita na onipotência das suas reflexões e conviç̧ões, busca propósitos de vida e à medida que vai se tornando adulto, sente a necessidade de cooperar com a sociedade, idealizar projetos e realizar-se pessoal e profissionalmente, o que a será então o ápice da aprendizagem e desenvolvimento na visão de Piaget (TRISTÃO, 2010).

Portanto, a teoria de Piaget, vem ressaltar que a aquisição de conhecimento, parte das experiências que o sujeito estabelece com o meio em que está inserido, e que este processo ocorre por meio de estágios, com sucessivas formas novas de aprendizagens. Sendo assim, o sujeito vai construindo o seu saber diante das situações problemas que precisa analisar, agir e resolvê-las, o que gera um desequilíbrio para posteriormente ocorrer a acomodação e assimilação, voltando novamente o indivíduo ao estado de equilibração, e assim efetivamente a aquisição do saber, isto acorre durante toda a vida, garantindo um processo continuo de aprender.

Vygotsky propõe estudar em sua teoria o que ele determina de funções superiores, que tornaria o homem diferente dos demais animais, compreendendo assim a cultura e história evolutiva da espécie humana. 
Este estudioso, e sua teoria sócio-histórica, ressalta uma forma diferente da teoria de Piaget sobre a aprendizagem. Para ele a aprendizagem não se dá em contato direto com o objeto de conhecimento, mas sim, por meio da mediação. O indivíduo seria capaz de manipular instrumentos, em conjunto com movimentos coordenados e aprimoramento de suas percepções, e por meio deste processo cognitivo e motor, a aprendizagem então iria proporcionar o desenvolvimento do sujeito (TRISTÃO, 2010).

Sendo assim, um estimulo pode ser mediado por uma lembrança já experienciada ou por uma outra pessoa, que levaria a mesma resposta. O sujeito não teria que interagir com objeto para de fato emitir a resposta esperada, como por exemplo, colocar a mão na tomada pode ser evitada pela criança por meio da lembrança de já ter tomado um choque e /ou por uma advertência de um adulto, e não propriamente ter que levar o choque de novo, para adquirir o conhecimento de não colocar a mão na tomada.

Vygotsky (1998), também ressalta que o instrumento seria o recurso facilitador para que o sujeito tenha em sua ação um suporte, e com intencionalidade, ele possa agir sobre o mundo. A criança também utiliza da imitação para manipular instrumentos, e ao emitir comportamentos de repetição, vai melhorando seu desempenho até chegar na resposta esperada, ou seja, o ato de imitar o outro também é capaz de desenvolver aprendizagens novas, que serão utilizadas ao longo da vida do sujeito. Já que o sujeito tem a intencionalidade em suas ações, neste sentido torna-se capaz de modificar o meio em que está inserido, sendo assim tornar-se agente transformador da sua história e cultura.

O instrumento, portanto, é o recurso externo que facilita as ações com o meio, mas criança também tem o recurso interno aplicado para solucionar questões psicológicas internas do sujeito, o que Vygotsky, denomina de símbolos ou signos (TRISTÃO, 2010).

Os signos ou símbolos, seria não só um objeto em si, mas um objeto com significado cultural, como é o caso da linguagem, que representa o principal signo cultural do homem. 
A linguagem tem a função de intercâmbio social e de pensamento generalizado. Tristão (2010, p. 165), afirma que "o pensamento generalizante remete à função da linguagem de ordenar o real, agrupando todas as ocorrências de uma mesma classe de eventos, objetos ou ocorrências sob um determinado conceito".

A linguagem nos bebês é ainda rudimentar e mais emocional, voltado para a ação prática e somente a partir dos dois anos de idade que a criança passa fazer uma associação entre linguagem e pensamento, atribuindo significado a sua comunicação.

A linguagem é um processo social em que a criança na necessidade de comunicar-se com o outro aprende a falar e posteriormente interioriza esta fala gerando assim o pensamento. Na transição da fala comunicativa para fala interiorizada, a criança passa da expressão da fala em voz alta, gradativamente para fala interiorizada que é o pensamento, ou seja, a criança deixa de narrar suas ações para pensar sobre estas.

O comportamento do sujeito estaria ligado diretamente a suas experiências sociais, que garantiriam seu desenvolvimento enquanto ser humano.

Como destaca Tristão (2010), o sujeito precisa além do instrumento e do símbolo, da mediação do outro para aquisição da aprendizagem e desenvolvimento, ou seja, sua capacidade de lidar com o mundo em que está inserido, por meio de suas habilidades, atitudes e conhecimentos.

Neste sentido, Vygotsky, apresenta o conceito de zona de desenvolvimento proximal ou próximo para explicar melhor como a criança aprende e se desenvolve a partir da sua interação com o meio.

A zona de desenvolvimento proximal seria a distância entre o nível de desenvolvimento real de uma criança e aquilo que se espera que ela alcance, ou seja, seu nível de desenvolvimento potencial. (TRISTÃO, 2010).

A aprendizagem se daria a partir daquilo que a criança já sabe fazer ( zona de desenvolvimento real), e após um tempo com o mediador ( um adulto ou um companheiro mais experiente) oferecendo instruções para um novo comportamento ( 
zona de desenvolvimento proximal), a criança seria capaz de aprender e realizar o comportamento sozinho, agora sem o auxílio do mediador ( zona de desenvolvimento potencial) (CARVALHO, 2005).

Desta forma, a figura do outro é de fundamental importância para que a criança aprenda e se desenvolva, contribuindo assim para a formação do ser de forma integral, favorecendo a maturação interpessoal e intrapessoal do sujeito. Este processo, porém, depende do nível de maturidade da criança, da sua capacidade cognitiva e de interação social, mas é um processo continuo que irá ocorrer por todo seu desenvolvimento.

Neste sentido Vygotsky difere de Piaget, pois não considera a aprendizagem em estágios lineares, mas em um ciclo continuo de conhecimentos, ou seja, cada vez que a criança atinge a zona de desenvolvimento potencial, ela passou por um processo de aprender, adquirindo e consolidando um novo saber, posteriormente está pronta para uma nova aprendizagem, e assim sucessivamente.

Contudo Vygotsky e Wallon, propõe uma concepção interacionista para o desenvolvimento da criança, considerando a constituição da desta como um sujeito social dentro de uma cultura concreta, que contribui para a sua formação enquanto sujeito.

Esta concepção vem de encontro com os pensamentos de Wallon, que também destaca que a aprendizagem não se dá em avanços graduais de estruturas mentais e lineares em relação ao desenvolvimento. Wallon (2010, p.33) "demonstra que, muito diferentemente disso, o desenvolvimento humano é marcado por avanços, recuos e contradições e, para melhor compreendê-lo, é preciso abandonar concepções lineares de análise e interpretação".

Para Wallon (2010), a criança atravessa diferentes estágios ao longo do seu processo de desenvolvimento, sendo possível demarcar alguns deles, pois se caracterizam entre momentos de maior interiorização e outros mais voltados para o exterior. 
Partindo destas referências, a teoria proposta por Wallon, se baseada na afetividade e inteligência, considerando as condições e característica do estágio de desenvolvimento, haverá uma alternância de momentos, hora de maior introspecção e hora de maior extroversão.

Para Wallon, a criança é constituída de um sistema que integra suas ações num processo de equilíbrio funcional que envolve motricidade, afeto e cognição, mas no qual cada estágio de desenvolvimento, descreve uma forma particular de ação que predomina sobre as outras. Nas interações sociais a criança passa a imitar o outo, e isto mostra que ela interiorizou o modelo, construindo com base nele uma imagem mental. A habilidade de reproduzir as ações, que mais adiante a criança passa a não mais imitar, mas a diferenciar-se do outro, reconhecendo o seu próprio eu. Os conflitos surgidos de suas interações com outras pessoas, possibilita a criança formar representações coletivas, que ampliam seu acesso ao meio simbólico e a cultura em que está inserida (OLIVEIRA, 2007).

Assim como Piaget, Wallon (2010) indicava que criança tem seu desenvolvimento marcado por estágios. No estágio, sócio-afetivo, que caracteriza a faixa etária de zero a um ano de idade, é considerada pelo estudioso como o estágio impulsivo nos três primeiros meses e posteriormente torna -se emocional, a criança interage com o mundo por meio das suas emoções afetivas e cria um mundo com significados próprios por meio das expressões tônicas. O bebê a partir da sua relação com o meio vai gradualmente tonando seus movimentos motores mais coordenados, e assim afetivamente diferenciando emoções mediante ao mundo em que está inserido.

No segundo estágio sensório-motor, que compreende a faixa etária de um a 03 anos de idade, nos primeiros dezoito meses a criança apresenta comportamentos sensórios-motores, e posteriormente passa a projeção se voltando mais para o exterior, ou seja, nesse estágio predomina as relações exteriores e a inteligência, que é eminentemente prática, e o pensamento se projeta em atos motores.

A criança conhece o mundo por meio da investigação e exploração, e o pensamento cognitivo está centrado no sincretismo subjetivo, ou seja, em fenômenos como a 
fabulação, a contradição, a tautologia e elisão. Nesta fase a imitação e os aspectos discursos, com base no outro é caraterística, o que favorece a aquisição da linguagem.

Dos 03 aos 06 anos, a criança está no estágio personalístico, nesta fase a criança passa a diferenciar-se do outro e a dar significados a sua própria ação, com o avanço da fala e da inteligência, características deste estágio se nomeia a concretude da personalidade (GALVÃO, 2000).

Neste estágio se forma a personalidade e a autoconsciência do sujeito, pois é refletindo as vezes por oposição ao adulto, outras por imitação destes, a criança vai aprendendo a repetir comportamentos sociais e assim alinhando sua postura em relação ao mundo.

No estágio quatro que corresponde a faixa etária dos seis aos onze de idade, a criança ter pensamentos conceituais, que a levará ao próximo estágio que é marcado pela capacidade de abstração e raciocínio simbólico o pensamento. Para Wallon, a criança passa do pensamento conceitual para a aquisição de funções mais complexas como a memória voluntária, a atenção e o raciocínio associativo (WALLON, 2010).

No último estágio, que já compreende a adolescência, a partir dos onze anos de idade, há grandes mudanças físicas e psicológicas, acentuando ainda mais a afetividade nesta fase, surgem os conflitos interno e esternos, proporcionando ao sujeito também uma fase de volta para si mesmo e autoafirma-se, para lidar melhor som suas transformações (GALVÃO, 2000).

Contudo para Wallon, o desenvolvimento permanece em processo por toda a vida do sujeito, e que a afetividade e cognição estarão dialeticamente presentes ao longo da sua existência, "[...] sempre em movimento, alternando-se nas diferentes aprendizagens que o indivíduo incorporará ao longo da vida." (WALLON, 2010, p.36).

Diante das concepções apresentadas, pode-se verificar que o desenvolvimento e a aprendizagem são processos que se complementam, ao interagir com o meio que o cerca o sujeito, de forma direta ou indireta, amplia sua capacidade motora, cognitiva e emocional desse modo constitui sua inteligência e afetividade, proporcionando ao 
indivíduo de fato se diferenciar dos outros animais, pois é capaz de refletir sobre si mesmo e sobre o mundo, transformando-se e modificando o meio que está inserido.

\section{METODOLOGIA}

Ao realizar uma pesquisa, esta deve conter um método que irá nortear o trabalho de modo planejado, para que se possa mensurar os dados coletados de forma fidedigna, garantindo

assim que os resultados possam ser relevantes, validando o trabalho científico.

Para Severino (2007) a ciência é sempre o enlace de uma malha teórica com dados empíricos, é sempre uma articulação do lógico com o real, do ideal com o real, pois toda modalidade de conhecimento, implica em uma condição prévia, um pressuposto relacionado a nossa concepção da relação sujeito/objeto.

Portanto, o fenômeno epistemológico deste trabalho incide sobre o conceito de aprender, partindo do conceito teórico de que aprender é a capacidade de adquirir conhecimentos para a adaptabilidade e solução de problemas no cotidiano do sujeito, considerando a realidade prática no ambiente escolar, diante das representações sociais dos docentes e pais/responsáveis de duas escolas de Educação Infantil, uma escola da zona rural e uma escola da zona urbana, na cidade no Vale do Paraíba, interior de São Paulo.

A pesquisa se caracteriza por seu caráter exploratório. Para Gil (2010), as pesquisas exploratórias são as que mais proporcionam familiaridade com o problema, tornandoo mais explícito e possível de elaboração de hipóteses.

Para Severino (2007, p. 123), "a pesquisa exploratória busca levantar informações sobre determinado objeto, delimitando assim um campo de trabalho, mapeando as condições de manifestações desse objeto". 
A pesquisa foi aplicada em duas escolas de Educação Infantil, apresentando perfil adequado para que o trabalho fosse realizado, situadas em uma cidade no Vale do Paraíba, interior de São Paulo.

A amostra contempla 12 docentes e 8 pais/responsáveis. Os grupos de sujeitos abordados foram escolhidos primeiro, partindo do número de professores e números de salas das unidades escolares, o que definiu um número inicial de participantes, 16 docentes e 32 pais/responsáveis. Posteriormente, foi feito o convite para os sujeitos, que após o esclarecimento da pesquisadora sobre a natureza do estudo e etapas da pesquisa, foi definido e fechado este número final de participantes.

Para coleta de dados, adotou-se como instrumentos, o questionário e a entrevista com grupo focal.

O questionário, para Gil (2010, p. 121), é um "[...] grupo de questões que são aplicadas aos entrevistados com o intuito de obter informações de suas experiências, crenças, sentimentos, valores, interesses, expectativas, aspirações, temores, comportamento presente ou passado etc.".

Para Marconi e Lakatos (2013, p. 100), o questionário é "[...] um dos instrumentos essenciais para a investigação social cujo sistema de coleta de dados consiste em obter informações diretamente do entrevistado."

Sendo assim, o questionário tem a função de possibilitar que as informações colhidas sejam traduzidas em números e contribuam para a análise quantitativa da pesquisa.

Já a escolha do instrumento grupo focal, para a coleta de dados nesta pesquisa se deu em virtude de ser uma forma mais flexível de conduzir as discussões com os participantes da pesquisa sobre o tema proposto, facilitando o processo de investigação, pois assim será possível coletar de forma mais pertinente e relevante, e em um período de tempo mais conciso, o conteúdo necessário para análise dos dados. 
Para Gondim (2003), o uso de grupos focais, está relacionado aos pressupostos e premissas do pesquisador. Alguns pesquisadores buscam neste tipo de recurso reunir informações necessárias para tomada de decisão, outros utilizam como promotor da auto - reflexão e da transformação social e ainda aqueles que usam como técnica para explorar um tema pouco conhecido, com o objetivo de oferecer material para novas reflexões e assim futuras pesquisas.

Segundo Gomes (2005), o grupo focal é constituído por um conjunto de pessoas selecionadas e reunidas pelo pesquisador, com o objetivo de discutir e comentar um tema, que é o objeto da pesquisa, a partir de suas experiências pessoais.

Em um projeto de pesquisa, segundo Gondim (2003), em que o pesquisador se apoia em grupos focais, precisa ter com clareza o propósito do estudo, pois as decisões metodológicas dependerão dos objetivos traçados, e isto irá influenciar na composição dos grupos, no número de participantes, na homogeneidade ou heterogeneidade dos mesmos.

Gomes (2005), também ressalta alguns passos relevantes que se deve considerar ao escolher os participantes para a realização do grupo focal como: os participantes devem ter alguma vivencia com o tema a ser discutido, de modo a ter elementos ancorados em suas experiências cotidiana; o convite deve ser atrativo aos participantes; assim como eles devem ter a liberdade de adesão; e o pesquisador precisa criar um pacto de confiança com os mesmos.

O pesquisador deve ser um mediador, diante do grupo focal, de modo a conduzir e facilitar as interações, sem direcionar um caminho ao grupo. Como afirma Gatti (2012), as interações devem ocorrer em caráter positivo, respeitando momentos de desenvolvimento para os participantes, no que se refere aos aspectos cognitivos, afetivos e de comunicação entre os elementos.

É importante que o registro seja realizado com eficiência, para garantir a coleta adequada dos dados (GATTI, 2012). Sendo assim, o pesquisador pode utilizar de recursos para a gravação que pode ser em áudio/visual com o equipamento de 
câmera de filmagem, ou somente áudio com o gravador, ou outros recursos em que se possa ter com clareza o registro das falas dos sujeitos.

Os equipamentos devem estar dispostos na sala para capitar com nitidez as falas dos participantes. Também pode ser utilizado registros em anotações por escrito para contribuir posteriormente na etapa de análise do conteúdo dos dados coletados. (GATTI, 2012)

Também é fundamental explicitar aos participante todas as etapas que serão feitas para que o grupo focal seja realizado, assim como solicitar a autorização por escrito dos participantes para que os dados coletados possam ser divulgados na pesquisa, $e$ garantir o sigilo para não identificar os participantes, assim proporcionar que eles possam se sentir livres para expor suas opiniões.

O tempo para realização do grupo focal, deve ter no mínimo noventa minutos e no máximo três horas, e quanto ao número de participantes, no mínimo seis e no máximo quinze pessoas, conforme ressalta Gatti (2012), para que as interações sejam ricas e não cansativas, proporcionando o aprofundamento no tema e maior participação dos sujeitos.

A transcrição do conteúdo também é uma etapa fundamental para o pesquisador que deve segundo Gatti (2012), considerar as interações dos membros do grupo, se atentando a sequência contextual, para a elaboração assertiva das codificações e categorizações do conteúdo coletado, facilitando assim a análise qualitativa do material.

Assim sendo, com o instrumento grupo focal, o pesquisador tem a possibilidade de verificar junto aos participantes as suas opiniões, assim como verificar os impactos das opiniões dos outros sobre as suas colocações, neste sentido verificar como as representações sociais do conceito de aprender são abordadas pelos sujeitos da pesquisa e como as mesmas são validadas ou não pelo grupo.

Para Gatti (2012) ao realizar a pesquisa utilizando grupos focais, é possível alcançar perspectiva diferentes sobre uma mesma questão, assim como compreender as ideias 
partilhadas pelos sujeitos no cotidiano, e verificar o nível de influência pelos quais os indivíduos são influenciados pelos outros.

Portanto, como ressalta Chizzotti (2010), a abordagem quantitativa, prevê a mensuração de variáveis preestabelecidas, procurando verificar e explicar sua influência sobre outras variáveis, mediante a análise de frequência de incidências e de correlações estatísticas. O pesquisador neste caso, descreve, explica e prediz os dados da sua pesquisa. A abordagem qualitativa, fundamenta-se em dados coligidos nas interações interpessoais, na coparticipação das situações dos informantes, analisadas a partir da significação que estão dando aos seus atos. O pesquisador neste caso participa, compreende e interpreta os dados da sua pesquisa.

Tanto a abordagem quantitativa quanto a qualitativa, possibilitará ao pesquisador enriquecer o trabalho, garantindo uma pesquisa fidedigna, objetivando os resultados, assim como possibilitando validar e promover novas reflexões sobre o tema abordado.

Com a compreensão dos instrumentos escolhidos para a elaboração desta pesquisa, apresento as etapas realizadas em campo e a aplicabilidade destes instrumentos.

O campo da pesquisa são duas escolas de Educação Infantil, localizadas no Vale do Paraíba, elas foram inicialmente observadas, de forma não participativa, ou seja, somente para observar os participantes na dinâmica das unidades escolares e as relações destes nas dependências das mesmas.

Esta fase foi realizada em 04 (quatro) dias alternados, para entender esta rotina escolar: entrada dos alunos com seus pais/responsáveis, assim como os docentes recebendo-os em suas salas de aula.

As verificações por meio da observação não participativa, foram anotas pela pesquisadora em formato de relatório da rotina escolar, para auxiliar posteriormente na análise dos dados.

Os critérios para a escolha dos grupos partiram da conversa com a Direção das unidades escolares, em que foi alinhado que seria convidado todos os professores 
ativos nas salas regulares das duas escolas e para cada sala regular, 02 pais/responsáveis seriam convidados para participar da pesquisa.

Sendo assim, o número total de participantes inicial foi de 52 pessoas, sendo 16 docentes e 36 pais/responsáveis, com o objetivo de atingir no mínimo 16 participantes, sendo 8 docentes e 08 pais/responsáveis.

Após definido os participantes, a Direção agendou uma data para apresentação do objetivo da pesquisa e as etapas do estudo que seriam realizadas. Foi marcado um encontro com o grupo de professores e um encontro com o grupo de pais/responsáveis, em horários diferentes, mas no mesmo dia. Na data marcada, estavam presentes 14 docentes, 16 pais/ responsáveis.

Foi realizada a explicação da pesquisa com cada grupo, com relação aos questionários, os participantes se interessaram em contribuir para com o estudo, mas com relação a etapa com o grupo focal, alguns participantes, apresentaram o argumento da disponibilidade de tempo, já que esta etapa demanda estar com o grupo no mínimo 90 minutos, portanto alguns participantes preferiram não fazer parte desta pesquisa.

Sendo assim, nesta data 30 questionários, foram entregues pela pesquisadora aos participantes, dentre os 30 questionários distribuídos, 20 questionários retornaram ao pesquisador, sendo que 12 questionários foram respondidos pelos docentes e 8 questionários foram respondidos pelos pais/responsáveis, e todos os 20 questionários respondidos foram utilizados nesta pesquisa.

$\mathrm{Na}$ etapa seguinte, foi agendado com os docentes e pais/responsáveis a data para a realização do grupo focal, e também compareceu os 12 docentes e os 08 pais/responsáveis que participaram da primeira etapa da pesquisa, fechando assim o grupo final de participantes desta pesquisa.

Foi realizado um grupo focal com os docentes e um grupo focal com os pais/responsáveis, por meio de dois encontros um em cada unidade escolar. Cada entrevista teve a duração de 1 h20min, com cada grupo. 
Para a realização do grupo focal, a pesquisadora elaborou previamente as questões que seriam abordadas junto aos participantes, como roteiro, além disso orientou os membros dos grupos como proceder diante das questões para que todos pudessem dialogar e todos pudessem ouvir de forma clara e objetiva as colocações de cada participante.

Como afirma Flick (2013, p. 119), o instrumento grupo focal é "[...] uma alternativa para entrevistar indivíduos e usar entrevistas em grupo em que a mesma pergunta é feita a vários participantes, que respondem um após o outro", permitindo que o grupo consiga estabelecer uma comunicação ordenada, respeitando o tempo de fala de todos os sujeitos que estão no grupo, favorecendo assim a uma melhor coleta de dados.

Dentre as orientações pontuadas foi ressaltado aos participantes que a pesquisadora iria fazer perguntas e que daria a cada um a oportunidade de responder. Cada participante deveria ouvir a resposta do colega e posteriormente poderia comentar ou completar a fala do mesmo, sendo importante os membros do grupo ouvir com atenção as colocações e procurar não interromper a fala do outro para que as colocações fossem finalizadas de forma mais assertiva.

Também foi informado ao grupo que seria importante coletar as falas dos mesmos por meio de gravação, para que posteriormente fosse transcrito e realizada a análise deste conteúdo pela pesquisadora. Após todos concordarem com a solicitação para a gravação foi realizada o grupo focal.

Estes instrumentos foram necessários para garantir de forma fidedigna os dados para a posterior análise tanto quantitativa, quanto qualitativa, de modo a oferecer resultados significativos.

Os dados coletados foram analisados por meio da análise de conteúdo, que "é uma metodologia de tratamento e análise de informações constantes de um documento, sob a forma de discursos pronunciados em diferentes linguagens: escritos, orais, imagens e gestos" (SEVERINO, 2007, p.121). 
Para Bardin (2009) a análise do conteúdo envolve um conjunto de técnicas de análise das comunicações de forma a alcançar procedimentos sistemáticos e objetivos de descrição do conteúdo das mensagens. Desta maneira obter indicadores (quantitativos ou não) que permitam a inferência de conhecimentos relativos às condições de produção/recepção (variáveis inferidas) destas mensagens.

Portanto, a análise de conteúdo irá buscar por meio de categorias analisar o que está por de trás das diferentes formas de discursos, analisando e interpretando a fala do sujeito, em busca de informações que pautem a pesquisa e ofereça ao pesquisador dados necessários para se chegar à resultados significativos, de forma fidedigna. $O$ percurso que Bardin (2009), propõe para a elaboração da análise de conteúdo será exemplificado na figura abaixo:

Figura 1 - Estrutura do Método de Análise de Conteúdo

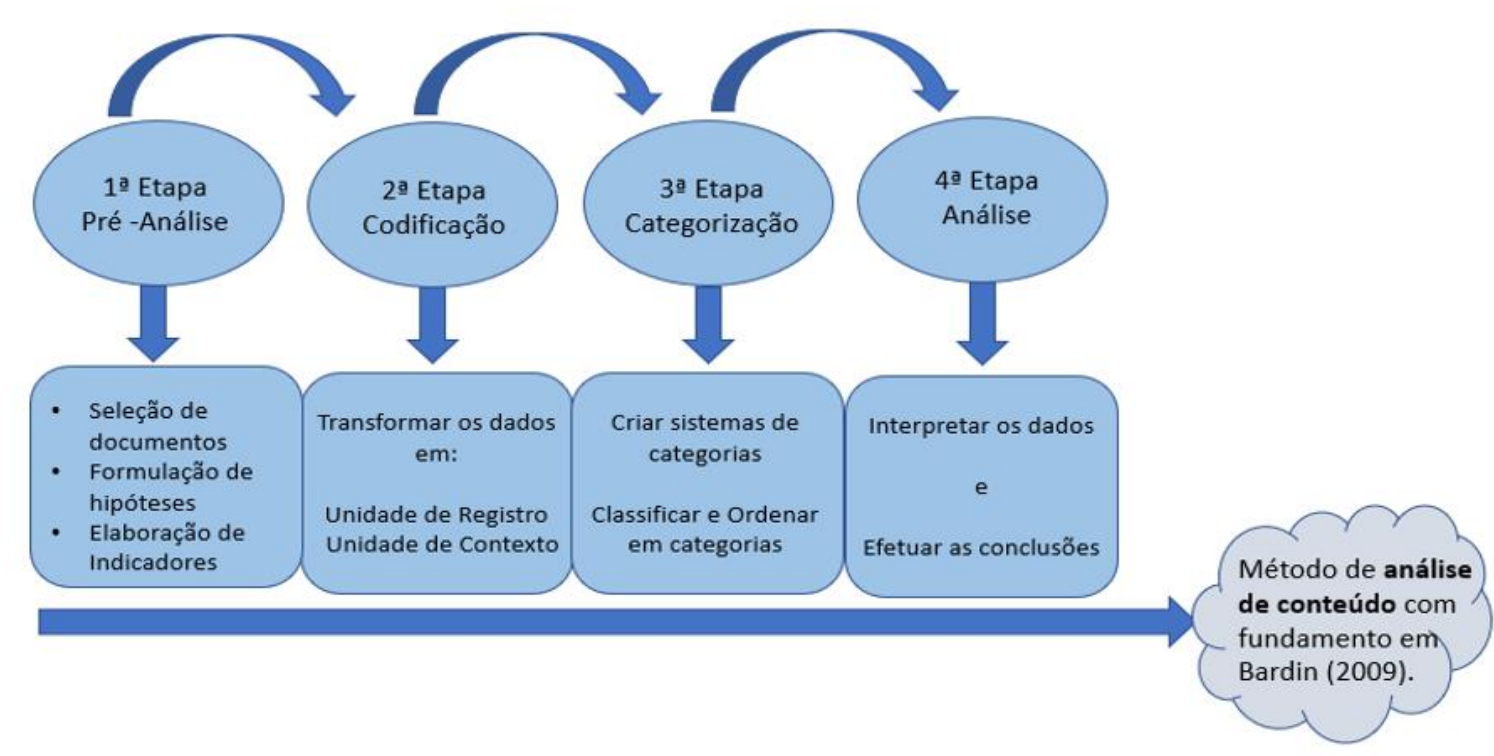

Fonte: Elaborado pela autora. 2020

Para próxima etapa, a estruturação das categorias, a pesquisadora buscou o auxílio do software IRAMUTEQ, para ajudar no processamento dos dados coletados.

Atualmente há vários softwares que auxiliam as pesquisas acadêmica-científica a separar e organizar informações, por meio da localização e segmentação de texto (s), 
como entrevistas, documentos, dentre outros, facilitando a análise de dados qualitativos.

O software IRAMUTEQ (Interface de $R$ pour les Analyses Multidimensionnelles de Textes et de Questionnaires), foi criado por Pierre Ratinaud, na França em 2009, e no Brasil este software passou a ser utilizado em 2013, inicialmente aplicado em pesquisas voltadas para o estudo das representações sociais, por isto foi escolhido pelo pesquisador com recurso coerente para este trabalho.

O software IRAMUTEQ realiza o processamento de dados dos textos e fornece resultados como a classificação hierárquica descendente (CHD), análise textuais clássicas, especificas, similitude e nuvem de palavras. Com estes resultados o pesquisador pode buscar informações, associar dados e explorar o conteúdo de modo a tornar mais rápido a análise dos dados, com rigor científico necessário para um trabalho de pesquisa.

Para a aplicabilidade do software IRAMUTEQ, o pesquisador utilizou o material gravado com os participantes na realização do grupo focal, que foi transcrito, e constituiu o corpus para a análise qualitativa.

Com o uso do software IRAMUTEQ, foi realizado o processamento de codificação, que fornece um dicionário de palavras, demonstrado por meio de um dendograma, sendo este utilizado como base para a análise cuidadosa dos dados e verificação das categorias.

Assim sendo, com o processamento dos dados, pelo software IRAMUTEQ, obteve-se 05 categorias, que representam as palavras que obtiveram maior porcentagem quanto à frequência média entre si e diferença entre elas.

Com os resultados obtidos pelo software e pela análise minuciosa de todo o material coletado, o pesquisador organizou estes conteúdos representativos das falas dos participantes sobre o aprender na Educação Infantil em 05 categorias que foram estruturadas, partindo dos conteúdos: aprender, criança, professor, escola (rural /urbana) e comunidade escolar. 
As categorias foram organizadas, assim possibilitou a composição da unidade de registro, de acordo com as falas dos participantes sobre estes determinados conteúdos, o que facilitou posteriormente estruturar a unidade de contexto e assim identificar de forma mais adequada os conteúdos necessários para a elaboração dos resultados.

\section{DISCUSSÃO}

Diante dos resultados obtidos, pode se identificar que os grupos estudados apresentam os quatro atributos que os caracterizam, inicialmente como um grupo primário e posteriormente, tornam se grupo funcional, pois seus membros desempenham papéis definidos na sociedade, diante do processo de escolarização e cuidados à criança.

Cada membro já possui sua consciência de pertença aos grupos, e se baseiam nas suas relações com outros grupos, nas suas necessidades pessoais e nos seus interesses, para confirmar sua identidade perante a coletividade.

Quanto ao tipo de coesão para os docentes fica claro a coesão da tarefa, em que os integrantes estão muito envolvidos com as atividades que realizam, considerando esta intrinsicamente valiosa, interessante e desafiadora.

Sendo assim, dentro do ambiente escolar, a coesão da tarefa ocorre porque o docente tem bem definido o seu papel e os seus objetivos como apresentado pelas políticas públicas e legislações que pautam a Educação Infantil, que define que o trabalho pedagógico deve contemplar o ser, como um todo (físico, psíquico, social e educacional), proporcionando por meio do trabalho pedagógico apresentado nos 06 direitos de aprendizagem e por meio dos campos de experiência, que a criança consiga se desenvolver por completo, tornando-se assim saudável e feliz, conceito reificado sobre o aprender na educação de 0 a 06 anos.

Este tipo de coesão pode ser verificado mais claramente no grupo dos docentes, pois estes têm bem definido as suas ações práticas pedagógicas assim como os objetivos de escolarização dos discentes. 
Já para os pais/responsáveis os objetivos são pautados no conceito de escolarizar os filhos, mas ainda não está claro na sua realidade prática social qual o melhor caminho para atingir este objetivo, como foi apontado nas respostas dadas pelos integrantes dos grupos tanto nos questionários, quanto no grupo focal.

No caso do grupo dos docentes há um grau maior de isoformismo, ou seja, os objetivos individuais de cada professor e os objetivos do grupo dos docentes são semelhantes, comparado ao dos pais/responsáveis, em que os objetivos individuais apresenta diferenças dos objetivos do grupo, com relação ao conceito de aprender.

Para os docentes a visão do conceito de aprender está mais alinhada ao perfil do conceito reificado pela BNCC (2017), já que para os professores a formação integral do aluno enquanto ser social é mais importante do que somente fazer o aluno ler, escrever e fazer conta, e isto já está sendo aplicado na realidade dos professores.

É importante ressaltar que em uma educação em que os ciclos educacionais acontecem e a cada fase há documentos legais que norteiam estes ciclos, para os docentes 0 acesso à estas informações é direto para que possam colocar em prática em suas atividades diárias com os alunos, mas para os pais/responsáveis este acesso muitas vezes é feito pela interpretação do grupo dos membros dos professores, sendo assim, a formação de um novo conceito de aprender neste sentido parte do todo coletivo (leis, normas, manuais, etc.) para o grupo dos doentes e posteriormente para o grupo dos pais/responsáveis.

Os grupos são influenciados e exercem o poder de influenciar, no caso dos docentes que representa a influência do grupo de minoria, considerando dentro da escola em relação a comunidade, embora pautados nos dados normativos, ainda não conseguiu, mudar a opinião dos pais/responsáveis, sobre o conceito de aprender.

Para pais/ e responsáveis o conceito de aprender na Educação Infantil ainda contempla a alfabetização, e o conceito comum de que as crianças precisam aprender a ler, escrever e a fazer conta, embora tenham a ciência de que os alunos devem ser menos cobrados diante deste aprender nesta fase. 
Neste ponto, o conceito de aprender para pais/responsáveis está centrado na sua realidade prática, já que o objetivo destes é proporcionar aos seus filhos o acesso mais "tranquilo" ao Ensino Fundamental, neste sentido as representações sociais estão pautadas no que este grupo entende como necessário para atender a suas expectativas sociais.

Também pode-se verificar que o brincar intencional é importante e está presente nas falas tanto dos pais/responsáveis, quanto na fala dos docentes. Contudo, para os docentes a representação social desta fala já está no conceito reificado prático, enquanto que para os pais/responsáveis, a familiarização do conceito ainda se encontra em fase de elaboração e não apropriação, ou seja, embora tenham o conceito reificado assimilado, na prática eles ainda questionam o brincar intencional como aprendizagem.

Para pais/responsáveis criar uma outra identidade diante de crenças e valores ainda não familiarizados pelo grupo gera instabilidade. Embora o conceito de aprender reificado já está bastante compartilhado pelo grupo de docentes, ainda não foi suficiente para a elaboração e apropriação do grupo de pais/responsáveis.

Isto também se confirma diante do questionamento dos grupos sobre a importância da Educação Infantil, pois enquanto os docentes continuam pontuando sobre formar um ser social capaz de estar no mundo e transformá-lo, oferecendo a criança um modelo de mundo diferente, os pais/responsáveis ainda reforçam os valores e crenças das suas representações sociais que é a necessidade de preparar a criança para a alfabetização. Mas, estes concordam com os docentes em termos de preparar a criança para ser mais independente e autônoma.

Diante da socialização dos grupos verifica-se que há uma determinação objetiva do contexto em que os indivíduos estão inseridos na sociedade com possibilidades concretas, seja materiais ou sociais bem definidas (área rural e área urbana, ensino público, dentre outros), há também uma formação histórica das necessidades pessoais de acordo com o estilo de vida e a transmissão ideológica que justifica as 
necessidades pessoais (ler e escrever e perspectivas de futuro ) o que reforça as falas dos pais/ responsáveis diante da alfabetização dos filhos.

Com relação a percepção do aprender, ambos os grupos declararam em suas falas que percebem que as crianças (filhos e/ou alunos) aprenderam no cotidiano, e que há uma troca desta aprendizagem já que o que a criança aprende na escola ela leva para casa e vice-versa.

Neste sentido, o conceito de aprender acaba por se reforçar e ao mesmo tempo se reconstruir nesta interação dos sujeitos em diferentes contextos na realidade social, pois esta troca vai além da unidade escolar e da casa da criança (filhos/alunos).

Também é importante ressaltar que as atitudes dos membros dos grupos, estão pautadas no afeto, que levam as pessoas a ser pró ou contra a um objeto social.

Diante das representações sociais sobre o aprender na Educação Infantil, este conceito é apropriado pelos grupos de forma diferente, pois suas ações sociais estão pautadas também em afetos diferentes, o que justifica suas escolhas (ou não), diante das necessidades do seu cotidiano.

Contudo, pode-se considerar que as necessidades cotidianas tanto dos docentes quanto dos pais/responsáveis estão pautadas em representações sociais próximas: com relação ao que influência o aprender e no que diz respeito ao poder público e a contribuição deste para com os alunos em oferecer suporte à escola, aos profissionais e a comunidade.

Também são próximas as representações sociais em relação a credibilidade e proximidade do professor na vida do aluno da escola rural dentro e fora da unidade escolar e estão próximas as representações sociais em relação a influência do docente no aprender dos alunos. Observa-se na fala dos pais/responsáveis e docentes que as crenças e valores são partilhados ao longo das gerações e isto contribui para reafirmar as representações sociais de que o professor influência no aprender dos discentes. 
É, também dentro dos grupos sociais que há o espaço para que a problematização do cotidiano, para o desencadear de novas relações e vínculos afetivos para a expressão de opiniões e sentimentos. O que pode ser observado quando os participantes comparam a escola rural e a escola urbana, suas falas são afetivas e expressam sentimentos sobre o lugar, as pessoas e as interações que mantém.

Os participantes ressaltam que comparando a escola urbana e a escola rural, o distanciamento do professor em relação aos alunos, e uma influência gradativa cada vez menor do docente no aprender do discente na zona urbana. As falas também confirmam as representações sociais que os grupos têm sobre as diferenças entre a escola da zona rural e a escola urbana, ou seja, que as pessoas no meio rural são mais próximas, afetivas e participam mais ativamente das atividades dentro e fora da unidade escolar, e isto influencia no aprender do aluno. Na escola urbana, as pessoas são mais distantes, buscam menos o afeto e participam menos das atividades dentro e fora da unidade escolar.

Os grupos estão familiarizados com estes conceitos que marcam as diferenças entre a escola da zona rural e escola rural, que em nossa sociedade é amplamente compartilhado, seja nas relações coletivas, seja em grupos, ou individual.

Contudo, é interessante observar que nas falas tanto dos docentes quanto dos pais/responsáveis há uma categorização reafirmada pelos grupos sobre os relacionamentos entre as pessoas, que estão ficando mais distante e que os valores éticos como respeito e valorização do outro estão gradativamente diminuindo.

Os participantes também compartilham do conceito representado por eles que o aprender na zona rural é mais rico, à medida que a criança tem acesso a vivências e experiências que na zona urbana ele não tem, o que favorece um aprender mais amplo, e a construção de saberes mais dinâmico e eficiente.

Com relação as representações sociais dos grupos sobre melhorias que possam contribuir para o aprender dos alunos, ambos os grupos compartilham que há a necessidade de apoio fora da unidade escolar, que para os docentes o conceito está 
pautado no contexto social mais amplo, é uma representação coletiva, que reflete os conceitos já familiarizados.

Para os participantes o conceito de aprender na Educação Infantil também é influenciado por representações que vão além daquelas apresentadas pelos grupos que estão inseridos no contexto escolar, é uma linguagem já compartilhada nas relações sociais mais amplas e justificadas pelas necessidades e realidades práticas experenciadas pelos membros dos grupos participantes da pesquisa.

Portanto, os dados refletem que os grupos participantes se encontram imbricados por vínculos interpessoais, que define suas identidades enquanto docentes e pais/responsáveis, tornado os fortes diante do cuidar e ensinar a criança, mas que ainda há poderes compartilhados e ações múltiplas entre os membros, que acabam por tornar difuso o conceito de aprender, pois na busca pela satisfação de cada grupo, com afetos individuais implicados, impactam diretamente em ações que refletem no processo de ensino e aprendizagem na Educação Infantil.

\section{CONCLUSÃO}

A pesquisa foi realizada com o objetivo de verificar quais as representações sociais dos docentes e pais/ responsáveis sobre o conceito de aprender, procurando por meio da investigação diante do contexto da escola da zona rural e a escola urbana analisar se há ou não diferenças e semelhanças em relação a este conceito.

Diante dos dados levantados pode-se verificar que o conceito de aprender para os docentes está pautado nos procedimentos legais e educacionais, que ao longo dos anos foram partilhados por meio do conhecimento acadêmico, e que foi gradativamente construído e elaborado pelos professores, e que diante da familiarização com o conceito, estes passaram a fazer parte da realidade prática dos docentes.

É por esta familiaridade do conceito que os docentes passaram a partilhar este saber com os pais/responsáveis, que estão em processo de construção e elaboração do "novo conceito de aprender", saindo do contexto da alfabetização e/ou do brincar 
intencional, para o aprender que promove a formação do cidadão de forma global que possa levar este conhecimento ao longo da sua vida.

O conceito de aprender está em construção para pais/responsáveis devido a sua representação social de que a Educação Infantil precisa preparar o aluno para a próxima etapa que é o ensino fundamental, contudo este, é um processo de continuidade do trabalho pedagógico de formação do ser em sociedade, o que para os docentes isto já é um conceito apropriado.

Pode-se verificar também que o conceito de aprender não foi partilhado pelos grupos como assistencialista ou como suporte aos pais/ responsáveis trabalhadores, e sim como um conceito mais voltado para a aprendizagem de conteúdo, o que reflete uma mudança também da Educação Infantil no contexto histórico, social e cultural na região em que a pesquisa ocorreu.

A pesquisa também trouxe dados em que se pode confirmar que a Educação Infantil é uma etapa importante para o aprender dos alunos que estão na faixa etária de zero a seis anos, para todos os participantes da pesquisa, contribuindo para as próximas etapas do aprender dos alunos.

Contudo, com representações diferentes, para pais/responsáveis para atender suas necessidades práticas de promover condições para o filho prosseguir os estudos de forma mais tranquila diante dos desafios dos anos seguintes de escolarização, já para os docentes este foco é considerado, mas vai mais além que é a formação do cidadão em sua totalidade, capaz de se inserir no contexto social de forma assertiva e eficaz, promovendo ampla bagagem de conhecimentos que os mesmos poderão usufruir ao longa da vida.

Neste sentido, pode-se constatar que as expectativas dos docentes e dos pais/responsáveis são divergentes com relação aos conteúdos pedagógicos, ou seja, o que a escola ensina na Educação Infantil não atende as expectativas de alfabetização dos pais, mas são convergentes diante da necessidade de promover uma aprendizagem lúdica, com um brincar intencional, que favoreça o aprender 
saudável, feliz e eficaz, o que também vem de encontro com a representação coletiva da Educação Infantil, reificada nos norteadores da educação como descritos no referencial nacional da Educação Infantil, nos manuais de aprendizagem para Educação Infantil, elaborados na cidade no interior de São Paulo etc.

Pode-se verificar que as representações sociais do conceito de aprender entre os grupos participantes da pesquisa, não apresentou diferenças significativas entre a escola da zona rural e a escola urbana, os saberes compartilhados em ambos os contextos estão pautados em representações semelhantes, o que favorece a uma uniformidade sobre o conceito de aprender diante de realidades escolares diferentes.

\section{CONSIDERAÇÕES FINAIS}

Identificou-se que as representações sociais sobre o conceito de aprender entre pais/responsáveis e docentes apresentou diferenças significativas quanto as expectativas dos conteúdos trabalhados na educação infantil, já que o conceito de aprender para os docentes está apropriado e familiarizado como prática docente em formar cidadãos de forma global, enquanto que para os pais/responsáveis o conceito ainda permanece como alfabetizar (saber ler e escrever). Também pode-se verificar que estas diferenças são evidenciadas tanto na escola rural quanto na urbana. Sendo assim, o conceito de aprender se baseia nas realidades práticas dos grupos participantes, que de acordo com seus valores e crenças o conceituam. Há de se considerar também que o conceito de aprender está tomando nova identidade a partir das relações entre os sujeitos ativos nas unidades escolares, que compartilham e elaboram a importância da educação infantil não mais como assistencial, mas como formação educacional.

\section{REFERÊNCIAS}

ANDRADE, Lucimary Bernabé Pedrosa de. Educação Infantil: discurso, legislação e práticas institucionais [online]. São Paulo: Editora UNESP; São Paulo: Cultura Acadêmica, 2010. 193 p. ISBN 978-85-7983-085-3. Available from SciELO Books. 
BARDIN, Laurence. Análise de Conteúdo. Lisboa, Portugal; Edições 70, LDA, 2009.

BRASIL. Base Nacional Comum Curricular: Educação Infantil e Ensino Fundamental. Brasília: MEC/Secretaria de Educação Básica, 2017.

BRASIL. Ministério da Educação e do Desporto. Secretaria de Educação Fundamental.

Referencial Curricular Nacional para a Educação Infantil / Ministério da Educação e do

Desporto, Secretaria de Educação Fundamental. — Brasília: MEC/SEF, 1998.

BRASIL. Senado Federal. Lei de Diretrizes e Bases da Educação Nacional: no 9394/96.Brasília: 1996.

BRASIL. Ministério da Educação. Base Nacional Comum Curricular - Documento preliminar. MEC. Brasília, DF, 2015.

BRASIL. Congresso Nacional. Plano Nacional de Educação. Lei 13.005/2014. Brasília, DF, 2014.

BOCK, A.M.B.; FURTADO, O.; TEIXEIRA, M.L.T; Psicologia: uma introdução ao estudo de psicologia.13ª edição. refom. e ampl. São Paulo: Saraiva, 2002.

CARVALHO, Diana Carvalho de. A Psicologia frente a educação e o trabalho docente. Psicologia em Estudo, Maringá, v. 7, n. 1, p. 51-60, jan./jun. 2005.

CHAMON, Edna Maria Querido de Oliveira. (org.) Representação social e práticas organizacionais. Rio de Janeiro: Brasport, 2009.

CHIZZOTTI, Antônio. Pesquisa em ciências humanas e sociais. 11 $11^{\text {a }}$ edição. São Paulo: Cortez, 2010.

FLICK, Uwe. Introdução à metodologia da pesquisa: um guia para iniciantes. Porto Alegre: Penso, 2013. 
GALVÃO, Izabel. Henri Wallon: uma concepção do desenvolvimento infantil, $7^{\mathrm{a}}$ edição. Petrópolis, RJ: Vozes, 2000.

GATTI, Bernardete Angelina. Grupo Focal na Pesquisa em Ciências Sociais e Humanas. Brasília: Liber Livro Editora, 2012.

GIL, Antônio Carlos. Como elaborar projetos de pesquisa. $5^{\text {a }}$ edição. São Paulo: Atlas, 2010.

GONDIM, S. M. G. Grupos focais como técnica de investigação qualitativa: desafios metodológicos. Paidéia, 12(24), 149-161, 2003.

GOMES, S. R. Grupo focal: uma alternativa em construção na pesquisa educacional. Cadernos de Pós-Graduação, São Paulo, v. 4, Educação, p. 39-45, 2005.

JODELET, Denise. (Org.). As representações sociais. Rio de Janeiro: EDUERJ, 2001.

MARCONI, Maria de Andrade., LAKATOS, Eva Maria. Metodologia do trabalho científico, 7ª̣ edição. São Paulo: Atlas, 2009.

MOSCOVICl, Serge. Representações sociais e investigações em Psicologia Social. 8ª edição. Petrópolis, RJ: Vozes, 2011.

OLIVEIRA, Zilma de Moraes Ramos de. Educação Infantil: fundamentos e métodos. 3ª edição. Cortez, São Paulo, 2007.

PERRENOUD, Phillipe. Avaliação: da excelência à regulação das aprendizagens: entre duas lógicas. Porto Alegre: Artes Médicas, 1999.

PIAGET, J. Seis estudos de psicologia. Rio de Janeiro: Forense Universitária, 1989.

RAIZER, Cassiana Magalhães. Organização e didática na Educação Infantil. São Paulo: Pearson Prentice Hall,2009. 
SILVA, João Roberto de Souza e ASSIS, Silvana Maria Blascovi de. Grupo focal e análise de conteúdo como estratégia Metodológica clínica-qualitativa em pesquisas nos Distúrbios do desenvolvimento. Cadernos de Pós-Graduação em Distúrbios do Desenvolvimento, São Paulo, v.10, n.1, p.146-152, 2010

SEVERINO, Antônio Joaquim. Metodologia do Trabalho Científico. 23를 edição. São Paulo: Cortez, 2007.

TRISTÃO, Daniela Pedrosa Fioravante. Psicologia da Educação. São Paulo: Person Education do Brasil, 2010.

VYGOTSKY, Lev Semyonovich. Aprendizagem e desenvolvimento intelectual na idade escolar. Em: Vigotskii, L.S., LURIA, A.R., Leontiev, A.N. (1998). Linguagem, desenvolvimento e aprendizagem. Trad: Maria da Penha Villalobos. (6 edição) (pp. 103-117). São Paulo: Ícone. (Trabalho originalmente publicado em 1933), 1998.

VYGOTSKY, Lev Semyonovich. A formação social da mente: o desenvolvimento dos processos psicológicos superiores.5ª̣edição. São Paulo Martins Fontes, 1989.

WALLON, Henry Paul Hyacinthe. Hélène Gratiot-Alfandéry; tradução e organização: Patrícia Junqueira. - Recife: Fundação Joaquim Nabuco, Editora Massangana, 134 p.: il. - (Coleção Educadores), 2010.

Enviado: Outubro, 2020.

Aprovado: Novembro, 2020. 